\title{
Blue Economy in Bangladesh: Next Resources Exist
}

\author{
Md Simul Bhuyan" ${ }^{1 *}$, Abu Sayeed Muhammad Sharif ${ }^{3}$ and Md Shafiqul Islam ${ }^{1}$ \\ ${ }^{1}$ Institute of Marine Sciences and Fisheries, University of Chittagong, Bangladesh \\ ${ }^{2}$ Halda River Research Laboratory, Department of Zoology, University of Chittagong, Chittagong, Bangladesh \\ ${ }^{3}$ Bangladesh Oceanographic Research Institute, Cox's Bazar, Bangladesh
}

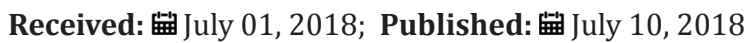

*Corresponding author: Md Simul Bhuyan, Institute of Marine Sciences and Fisheries, University of Chittagong, Bangladesh, and Halda River Research Laboratory, Department of Zoology, University of Chittagong, Bangladesh

\begin{abstract}
Blue economy is the basis of a sustainable development of the ocean-based country like Bangladesh. Sustainable development is the development that meets the needs of the present without compromising the ability of future generations to meet their own needs. Blue economy is the use of sea and its resources for sustainable economic development and the concept is new in Bangladesh and South Asia. Long-term prosperity can be achieved using sea area by a country befitting the wellbeing of all citizens and the mankind conserving the environment. This review focused on the importance of blue economy in Bangladesh along with some meaningful recommendations for successful execution of Blue economy concept.
\end{abstract}

Keywords: Blue economy; Resources; Sustainable development; Recommendations; Bangladesh

\section{Blue Economy}

The term first derived from Gunter Pauli's book, "The Blue Economy: 10 years, 100 innovations, 100 million jobs" (2010). The term "Blue Economy" means sustainable use of ocean resources for economic growth, improved livelihoods and jobs, and ocean environment health [1]. Generally, in the contexts of economics, agriculture, and conservation "blue economy" is a sticker that refers to the use of the sea and its resources for sustainable economic development. More specifically, it basically refers to any economic activity in the marine sector, whether sustainable or not" [2].

\section{Announcement of Blue Economy}

The "Rio +20" United Nations Conference on Sustainable Development (UNCSD), held in Rio de Janeiro, 20-22 June 2012, focused on two (2) main themes [3]. These themes are the growth and sophistication of the Institutional Framework for Sustainable Development and the development of the "Green Economy" concept.

\section{Ocean's Contribution}

Ocean cover most of the planet hydrosphere [4]. Oceans are covering approximately $71 \%$ of Earth's surface and $90 \%$ of the
Earth's biosphere [5]. The ocean contains $97 \%$ of Earth's water, but less than $5 \%$ of the World Ocean has been explored [5]. Ocean is the major constituent of Earth's hydrosphere as it is integral to life, forms part of the carbon cycle, and influences climate and weather patterns. Oceans are suitable habitat of 230,000 known species and many unknown species (in total possibly over two million) [6]. Primitive life first evolved in the oceans. Ocean act as a natural or artificial reservoir that amasses and stores some carbon-containing chemical [7]. Oceans absorb carbon dioxide $\left(\mathrm{CO}_{2}\right)$ [8], release oxygen $\left(\mathrm{O}_{2}\right)$ [9], recycle nutrients and regulate global climate and temperature [10]. Moreover, Oceans provide food and livelihoods of the global population and are the vital way of transport for $80 \%$ of global trade [3]. Tourism industries are established along the marine and coastal environment. The seabed currently provides $32 \%$ of the global supply of hydrocarbons and renewable "blue energy" production from wind, wave, tidal, thermal and biomass sources. Ultimately it offers 31 million direct full-time jobs in 2010, around $1 \%$ of the global work force and about $1.5 \%$ of the global workforce actively employed [11] (Figure 1). 


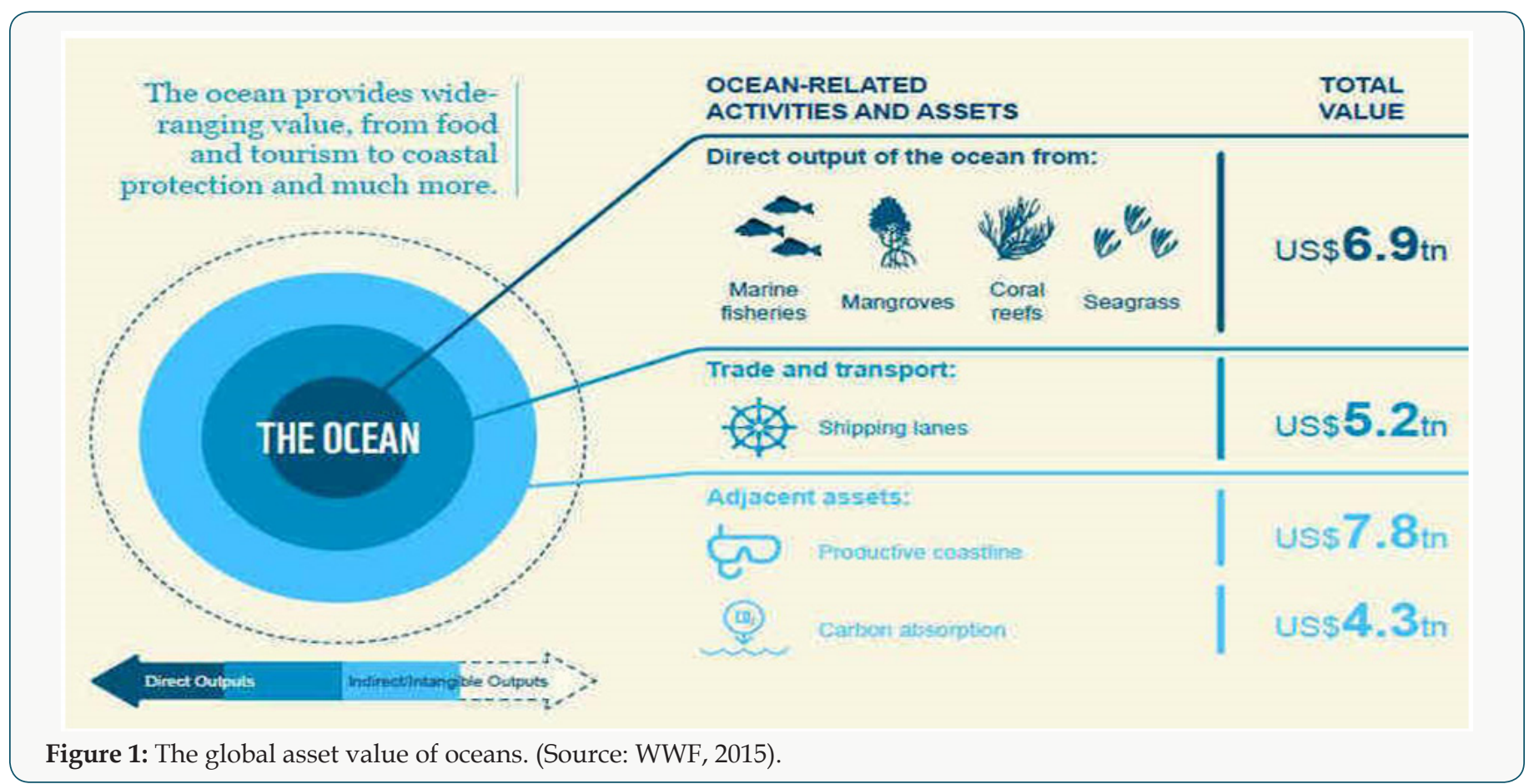

\section{Established and Emerging Sector Based on Ocean}

The scenery of traditional maritime industries will be faced substantial change in the upcoming decades due to global economic growth and increasing demand. For example, in the shipping sector, container traffic looks set to continue to grow very fast, with volumes likely to triple by 2035 [12]. Although the main driver of overall production will be aquaculture, but fisheries production worldwide is projected to expand by around a fifth over the next ten years [13]. The established and emerging ocean-based industries are include: capture fisheries, marine aquaculture, seafood processing, deepand ultra-deep water oil and gas, shipping offshore wind energy, ports ocean renewable energy, shipbuilding and repair, marine and seabed mining, offshore oil and gas (shallow water), maritime safety and surveillance, marine manufacturing and construction marine biotechnology, maritime and coastal tourism, high-tech marine products and services, marine business services and education and dredging [11].

\section{Scope of Blue Economy}

Blue Economy deliver chances for sustainable, clean, reasonable blue growth in both traditional and emerging sectors; fishing, marine biotechnology, minerals, marine, renewable energy, marine manufacturing, shipping, port \& maritime logistics, marine tourism \& leisure, marine construction, marine commerce, marine ICT, education and research (Sources: Compiled from Morrissey (2010), EIU (2015a), Govt. of Ireland (2012) and Marine Institute).

\section{Blue Economy for Bangladesh}

Ideas, principles and norms of Blue Economy can play significant role in the context of poverty eradication, food and nutrition security, mitigation and adaptation of climate change and generation of sustainable and inclusive livelihoods [14]. To obtain these balanced approaches between conservation, development and utilization of marine and coastal eco-systems is needed. To meet the next generation demand it is high time to explore the ocean resources. For this extensive and integrated research can play an important role (Figure 2).

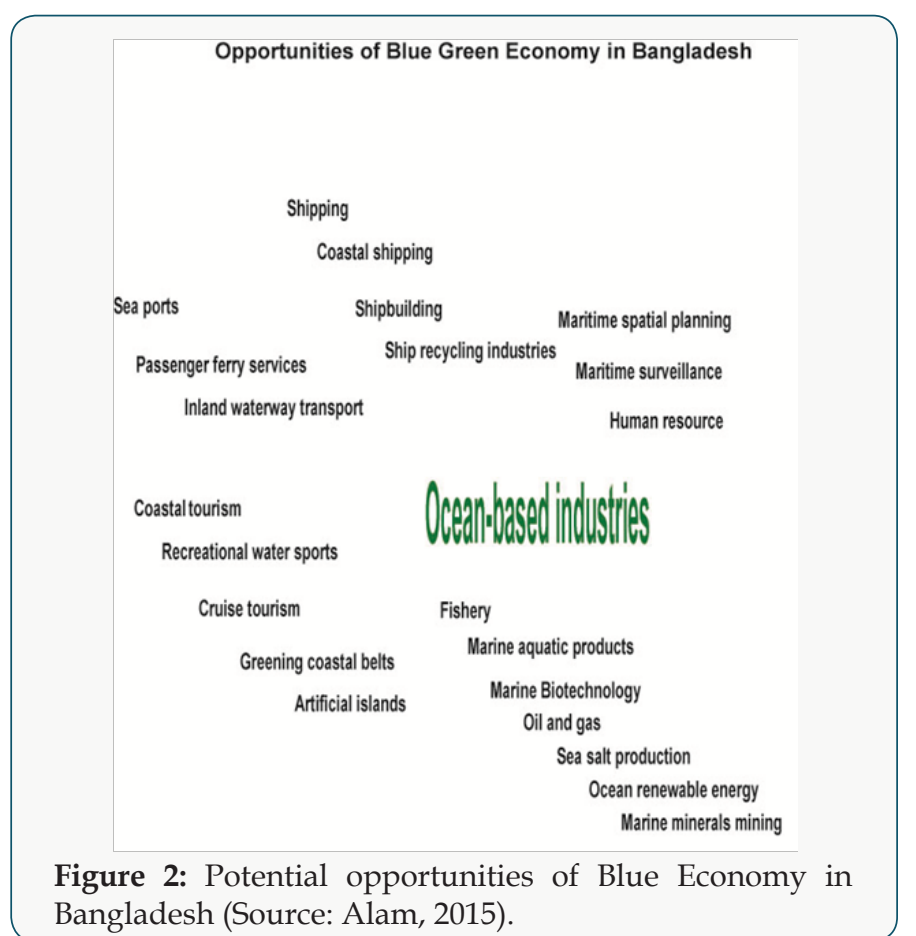

\section{Opportunities of Blue Economy in Bangladesh}

Bangladesh is blessed with the Bay of Bengal, the largest Bay in the world. It has massive potentials for the Blue Economy as the 
coastal states have every right to explore and use resources in their maritime boundaries [15]. Blue Economy provides wide range of services. It offers chances for the clean and sustainable advancement of the marine resources. Some resources are appearing as an emerging sector to develop. All the existing and emerging sectors need to modify for attaining the sustainable growth of the country. Strong relationship was found between poverty eradication and better protection and restoration of habitat, marine fishery resources and biodiversity.

\section{Striking Characteristics of Blue Economy in Bangladesh}
a) Government won the maritime boundary from India and Maynmar.
b) Establishment of a marine authority named "National Maritime Research Institute".
c) Establishment of a university for further Research Work "BSMR Maritime University".
d) The government are trying to establish a deep-sea port [16].

\section{Conclusion and Recommendations}

From the above discussion it can be concluded that, Bangladesh has immense potential to utilize the Blue Economy concept for the betterment of its economy [17]. To attain the expected goal different stakeholders should work together. Some recommendations can be drawn for the successful implement of Blue Economy concept.

a. Political stability and strong commitments from politicians

b. Enough budget for research in the national budget plan

c. Financial support from national and international agency

d. Creating awareness about the importance of ocean through mass media (e.g. TV, Radio, Newspaper etc.)

e. Organizing workshops, seminars and conferences in regular basis

f. Media coverage of workshops, seminars and conferences

g. Scholarships and internships for the young researchers from University

h. Ensurance of good outputs by the scholarship holders and publication of the research outputs in the international peerreviewed journal

i. Encourage students to be innovative through "Ocean Resources Competition" all over the country and announcing handsome prize money for the winner j. Establishment of new ocean-based University along the seashore

k. Ocean based research laboratory in coastal area (e.g. Bangladesh Oceanographic Research Institute, Cox's Bazar)

l. Deep Sea Research Laboratory (DSRL) with modern instruments (e.g. Submarine and Deep-submergence vehicles etc.)

m. Give priority on the existing institutions (e.g. Institute of Marine Sciences and Fisheries, University of Chittagong, Chittagong) that work on the ocean

n. Changing traditional attitude on some area (e.g. employment, offer project etc.)

o. Establishment of a new ministry named "Ministry of Ocean Resource Exploration"

\section{Acknowledgement}

Authors expressed their special thanks to Md. Abdullah-AlMamun., Institute of Marine Sciences and Fisheries, University of Chittagong, Chittagong, Bangladesh for his encouragement and valuable suggestions.

\section{References}

1. (2017) What is the Blue Economy? The World Bank.

2. (2015) World Worldlife Fund (WWF), Ocean Economy Report.

3. (2012) Review of Maritime transport 2012. UNCTAD.

4. (2012) Word Net Search-ocean. Princeton University.

5. (2012) National Oceanic and Atmospheric Administration (NOAA) Ocean Noaa gov.

6. Drogin B (2009) Mapping an ocean of species. Los Angeles Times.

7. Yousaf B, Liu G, Wang R, Abbas Q Imtiaz M, et al. (2016) Investigating the biochar effects on C-mineralization and sequestration of carbon in soil compared with conventional amendments using stable isotope $(\delta 13 \mathrm{C})$ approach. GCB Bioenergy 9(6): 1085-1099.

8. (2017) Ocean Acidification. National Geographic.

9. (2010) Oxygen. World Ocean Review.

10. Bristow LA, Mohr W, Ahmerkamp S, Kuypers MMM (2017) Nutrients that limit growth in the ocean. Curr Biol 27(11): 474-478.

11. (2016) The Ocean Economy in 2030. OECD Publishing, Paris.

12. (2015) OECD, Oversupply in the shipbuilding industry.

13. (2015) OECD and FAO. OECD-FAO Agricultural Outlook 2015. OECD Publishing, Paris.

14. Alam MK (2015) Ocean/Blue Economy for Bangladesh. MoFA.

15. Bari A (2017) Our Oceans and the Blue Economy: Opportunities and Challenges. Procedia Engineering 194: 5-11.

16. Hossain MA (2017) The prospect and challenges of Blue Economy in Bangladesh.

17. (2015) What a 'blue economy' really is-WWF's perspective. WWF Global. 


\section{(C) (i) This work is licensed under Creative} To Submit Your Article Click Here:

Submit Article

Assets of Publishing with us
- Global archiving of articles
Petrochemical Sciences

